\section{Palaeomagnetic Evidence for Rotation of Sardinia during the Early Miocene}

Geological and palaeomagnetic evidence indicates that after the Permian the Corso-Sardinian plate rotated counterclockwise with respect to stable (extra-Alpine) Europe ${ }^{1-6}$. Palaeomagnetic directions from Late Oligocene/Early Miocene rocks can be interpreted as indications for a Late Tertiary rotation ${ }^{5,7}$. Here we present additional palaeomagnetic data from volcanic rocks and tuffites of Tertiary age, collected near the village of Castelsardo on the northern coast of Sardinia (Fig. 1).

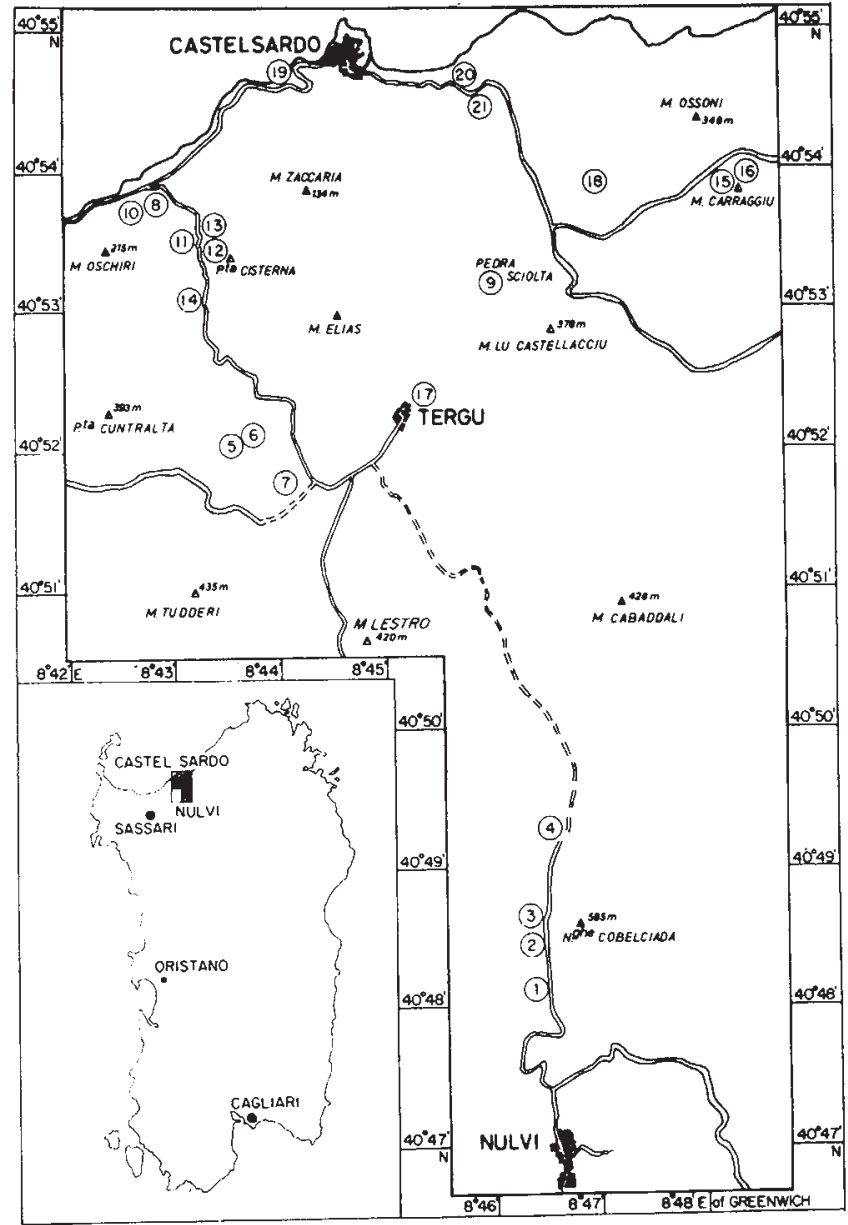

Fig. 1 Map of the Castelsardo area with sampling sites indicated.

The volcanic rocks of northern Sardinia consist of andesites, trachytes and liparites. Tuffs, tuffites and sediments are intercalated. The exposures are discontinuous, the sediments show rapid facies transitions, and block faulting hampers detailed correlation of the volcanic rocks. Near Castelsardo, however, it is possible to map in detail a number of stratigraphical units, from which oriented hand samples were collected. The geological relationships of these units are depicted schematically in Fig. 2. The two principal andesite bodies in the area (indicated as $\alpha$ on the geological map of Moretti et $a l^{8}$ ) underlie all other sampled units, the oldest of which are Aquitanian. Comparison with other volcanic units outside the Castelsardo area suggests that the andesites are not older than Middle Oligocene ${ }^{9}$. Their age must be similar to that of the Alghero trachyandesites; a contemporaneity supported by similar palaeomagnetic directions.

The overlying lacustrine sediments, tuffs and tuffites are dated as Aquitanian/Langhian on the basis of contained

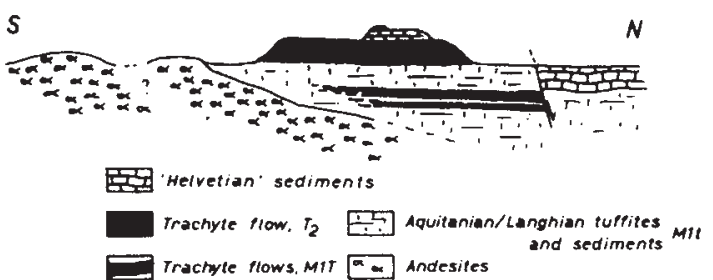

Fig. 2 Schematic stratigraphical section of the sedimentary and volcanic rocks which were sampled for this study.

fossils (refs. 10,11 and M. L. Colalongo, personal communication). Intercalated in the sediments and tuffites (MIt) are two flows of trachyte (M1T). Samples from two sites within M1t and from seven sites within M1T yielded similar palaeomagnetic results. Small local andesite plugs and intercalations also occur, but they have not been sampled extensively because of uncertain stratigraphical relationships.

There is a thick trachyte flow capping the sequence of M1t sediments, tuffs and M1T flows. Southeast of Castelsardo this flow is usually denoted as $T_{2}$, southwest of Castelsardo $\mathrm{T}_{2} \delta$ and $\mathrm{T}_{3}$ are also used. Sampling was restricted to the exposures denoted as $\mathrm{T}_{2}$, because the geological correlation between the $T_{2}$ exposures is unambiguous and because its age is better established: for instance $2 \mathrm{~km}$ southeast of Castelsardo, the flow is overlain by marine sediments of Serravallian (Helvetian auct.) age ${ }^{11}$.

The natural remanent magnetizations of ninety-five hand samples from twenty-one sites have been studied in the

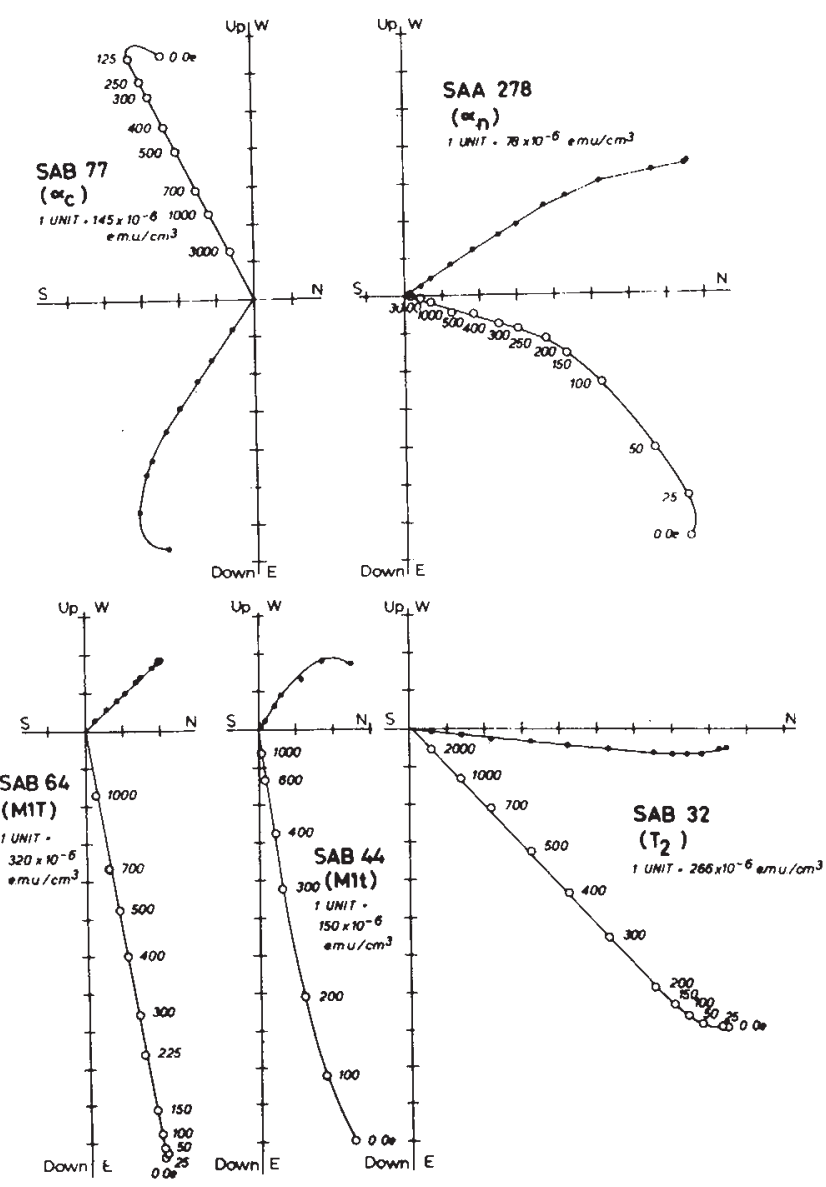

Fig. 3 Demagnetization diagrams obtained from samples from the five stratigraphical units investigated. Plotted points represent the end points of the magnetization vector--in orthogonal projection-during progressive AF demagnetization. Full symbols represent projections on the horizontal plane; open symbols represent projections on the $\mathrm{N}-\mathrm{S}$ vertical plane. 
Palaeomagnetic Laboratory of the State University of Utrecht. The intensities of the magnetizations were of the order of $200 \times 10^{-6}$ to $9,000 \times 10^{-6} \mathrm{emu} \mathrm{cm}{ }^{-3}$; the $Q$-values varied between 0.4 and 30 , but were generally higher than 1.0. Stepwise demagnetization in alternating fields of up to 3,000 Oersted generally revealed that secondary magnetizations play no important role and that they can be easily removed in the lower alternating fields (Fig. 3). Fields of 3,000 Oersted usually also completely eliminated the characteristic magnetizations. The direction of the characteristic magnetization was determined from the final straight trajectory of the demagnetization diagrams (for example, the straight paths between 300 and 1,000 Oersted in Fig. 3). The "within-site" scatter of the directions of magnetization was very small and generally decreased even more on demagnetization.
In Fig. 4 we plot the mean site directions of these stratigraphical units (with respect to the original horizontal) together with those previously published for Tertiary rocks from Sardinia. Both the inclination and the declination values show a large variability. The variability in declinations is remarkable because here there secms to be a consistent trend: the oldest rocks show the most westerly declinations (Fig. $4 a$ ), younger rocks a NNW declination and the youngest rocks (flow $T_{2}$ and the two Plio-Pleistocene basaltic formations $\beta_{1}$ and $\beta_{2}$ ) possess a direction close to due north (Fig. $4 b$ ).

This change in declination could be the result of a long lasting Late Oligocene-Early Miocene excursion of the geomagnetic dipole field, but such an event has not been demonstrated for this period. We conclude, therefore, that it is more likely that the change in declination represents a

\begin{tabular}{|c|c|c|c|c|c|c|c|c|c|c|}
\hline \multicolumn{11}{|c|}{ Table 1 Summary of the Tertiary Palaeomagnetic Data from Sardinia } \\
\hline \multirow[b]{2}{*}{ Age } & \multirow[b]{2}{*}{ Formation } & \multirow{2}{*}{$\underset{\text { symbol }^{8}}{\text { Map }}$} & \multirow{2}{*}{$\begin{array}{l}\text { Site No. } \\
\text { Fig. } 1\end{array}$} & \multirow{2}{*}{$\begin{array}{l}\text { Decl. Incl. } \\
\text { per site }\end{array}$} & \multicolumn{5}{|c|}{ Mean direction of magnetization } & \multirow{2}{*}{$\begin{array}{l}\text { Pole position } \\
\text { and }(\mathrm{dp}, \mathrm{dm})\end{array}$} \\
\hline & & & & & $N(n) \dagger$ & K & $a_{95}$ & Decl. & Incl. & \\
\hline \multirow{5}{*}{ 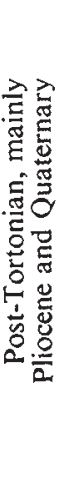 } & Basalts near Logudoro ${ }^{7}$ & $\beta_{1}$ & & $\begin{array}{r}14.5+56.5 \\
353.5+52.5 \\
347.5+49.5\end{array}$ & $3(8)$ & 80 & 14 & 357.5 & +53.5 & $\begin{array}{l}8.3 \mathrm{~N}, 154 \mathrm{~W} \\
(13.5 ; 19.5)\end{array}$ \\
\hline & Basalts near Logudoro ${ }^{7}$ & $\beta_{2}$ & & $\begin{array}{l}360+46.5 \\
355.5+46.5 \\
351+41\end{array}$ & $3(9)$ & 321 & 7 & 355.5 & +44.5 & $\begin{array}{l}75 \mathrm{~N}, 155.5 \mathrm{~W} \\
(5.5 ; 8.5)\end{array}$ \\
\hline & Basalts near Orosei ${ }^{1.3}$ & $?$ & & 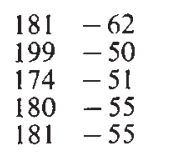 & $5(34)$ & 120 & 7 & 183 & -55 & $\begin{array}{l}84.5 \mathrm{~N}, 162.5 \mathrm{~F} \\
(7 ; 10)\end{array}$ \\
\hline & Basalts from Campidano ${ }^{13}$ & $?$ & & $183-51$ & $1(9)$ & - & - & 183 & -51 & $\begin{array}{l}81.5 \mathrm{~N}, 171 \mathrm{E} \\
(9 ; 13.5)\end{array}$ \\
\hline & Basalts near Campeda ${ }^{13}$ & $\beta_{1}+\beta_{2}$ & & $342+50$ & $1(5)$ & - & - & 342 & +50 & $\begin{array}{l}72.5 \mathrm{~N}, 108.5 \mathrm{~W} \\
(9 ; 13.5)\end{array}$ \\
\hline \multirow[t]{2}{*}{ 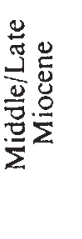 } & Castelsardo trachyte (our work) & $T_{2}$ & $\begin{array}{l}17 \\
18 \\
19 \\
20 \\
21\end{array}$ & $\begin{array}{r}359.5+51 \\
359+46 \\
6.5+52 \\
5.5+46.5 \\
7.5+62.5\end{array}$ & $5(25)$ & 131 & $6.5^{\circ}$ & 3.5 & +51.5 & $\begin{array}{l}81 \mathrm{~N}, 170 \mathrm{~F} \\
(6 ; 9)\end{array}$ \\
\hline & $\begin{array}{l}\text { Aquitanian/Langhian tuffites of } \\
\text { Castelsardo (our work) }\end{array}$ & M1t & $\begin{array}{l}8 \\
9\end{array}$ & $\begin{array}{l}334+64 \\
321.5+73.5\end{array}$ & $2(9)$ & 120 & $23^{\circ}$ & 329 & +69 & $\begin{array}{c}66 \mathrm{~N}, 42 \mathrm{~W} \\
(33 ; 39)\end{array}$ \\
\hline 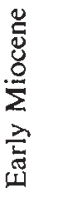 & $\begin{array}{l}\text { Aquitanian/Langhian trachyte } \\
\text { flows near Castelsardo (our } \\
\text { work) }\end{array}$ & Mlt & $\begin{array}{l}10 \\
11 \\
12 \\
13 \\
14 \\
15 \\
16\end{array}$ & $\begin{array}{l}324+72.5 \\
327.5+69 \\
287+62 \\
301+56 \\
272+51.5 \\
295.5+55.5 \\
305.5+56\end{array}$ & $7(32)$ & 46 & $9^{\circ}$ & 298.5 & +61.5 & $\begin{array}{l}45 \mathrm{~N}, 57.5 \mathrm{~W} \\
(10.5 ; 14)\end{array}$ \\
\hline \multirow{5}{*}{ 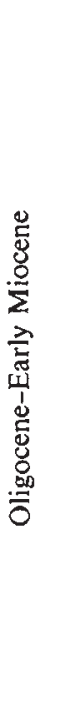 } & $\begin{array}{l}\text { Andesite body, south of Castel- } \\
\text { sardo (between Nulvi and } \\
\text { Tergu (our work) }\end{array}$ & $\alpha_{n}$ & $\begin{array}{l}1 \\
2 \\
3 \\
4\end{array}$ & $\begin{array}{l}325.5+11.5 \\
318.5+12.5 \\
325.5+5 \\
326+14\end{array}$ & $4(17)$ & 234 & $6^{\circ}$ & 324 & +11 & $\begin{array}{l}42.5 \mathrm{~N}, 119 \mathrm{~W} \\
(3 ; 6)\end{array}$ \\
\hline & $\begin{array}{l}\text { Andesite of Contralta near Cas- } \\
\text { telsardo (our work) }\end{array}$ & $\alpha_{\mathrm{s}}$ & $\begin{array}{l}5 \\
6 \\
7\end{array}$ & $\begin{array}{l}130.5-65 \\
110-62.5 \\
119-48.5\end{array}$ & $3(11)$ & 64 & $15.5^{\circ}$ & 119.5 & -59 & $\begin{array}{c}45 \mathrm{~N}, 62 \mathrm{~W} \\
(17.5 ; 23)\end{array}$ \\
\hline & Alghero trachyandesites 5 & $T_{1}$ & & $\begin{array}{l}148-47 \\
317+43 \\
324.5+42.5 \\
341+16\end{array}$ & & & & & & \\
\hline & & & & $\begin{array}{l}153-40 \\
162.5-43 \\
146-28 \\
138.5-43 \\
284+54.5 \\
283+49\end{array}$ & $10(59)$ & 20 & $11^{\circ}$ & 322 & +42 & $\begin{array}{l}54 \mathrm{~N}, 95 \mathrm{~W} \\
(12.5 ; 17)\end{array}$ \\
\hline & $\begin{array}{l}\text { Pre-Helvetian volcanics near } \\
\text { Logudoro }^{7}\end{array}$ & $\begin{array}{c}\alpha\left(\alpha_{1} ?\right) \\
T_{1} \\
\alpha\left(\alpha_{2} ?\right) \\
T_{2} \\
T_{3} \\
T_{3}^{\prime}(2) \\
\alpha_{3}\end{array}$ & & $\begin{array}{l}344+66.5 \\
120.5-35.5 \\
307+49 \\
341.5+29.5 \\
345+24.5 \\
337+64.5 \\
169-25.5\end{array}$ & $7(28)$ & 12 & $18^{\circ}$ & 332.5 & +43.5 & $\begin{array}{l}62.5 \mathrm{~N}, 106.5 \mathrm{~W} \\
(14 ; 22.5)\end{array}$ \\
\hline
\end{tabular}

$\dagger N$, Number of sites or flows, used in the statistical analysis; $n$, the number of samples investigated. 
Fig. 4 Equal area projections of the site-mean directions of magnetization of the Tertiary rocks from Sardinia (see also Table 1). $a$, The Oligocene/Lower Miocene rocks; $b$, the Middle Miocene and younger rocks. All symbols are projections of the impingement points on the lower hemisphere; open symbols indicate palaeomagnetic directions which had to be inverted to impinge the lower hemisphere (reversed polarity), full symbols indicate directions with normal polarity. $\square$, $\square$, Ref. $7 ; 0,9$, ref. $5 ; \Delta, \alpha_{c}$ andesite; $\boldsymbol{\gamma}, \alpha_{n}$ andesite; $\diamond$ MIt sediments and tuffs; $\diamond$, M1T flows; $\star, T_{2}$ flow; $\square$, , ref. $13 ;$, ref. 7 .
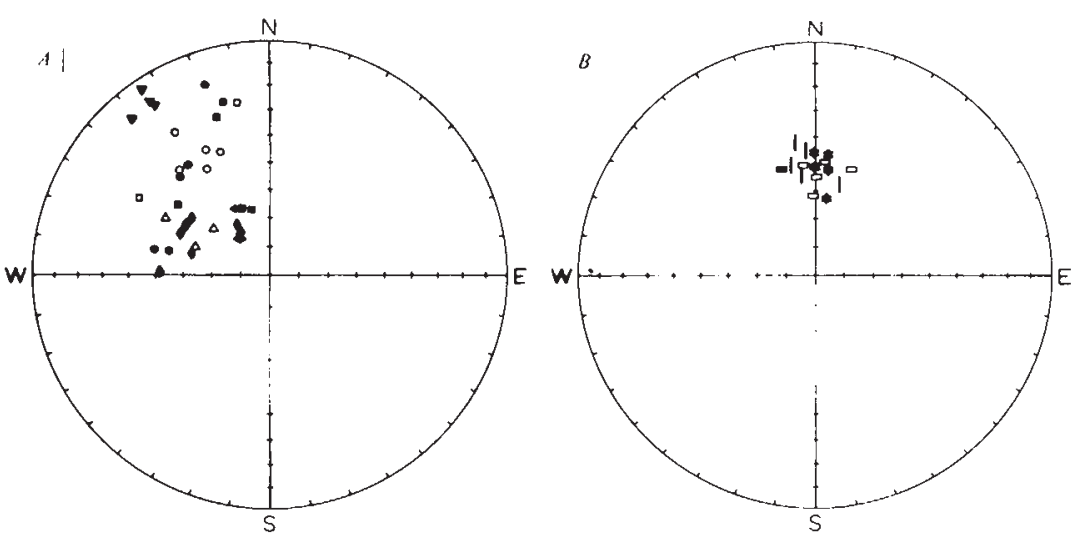

counterclockwise rotation of Sardinia over an angle of approximately $50^{\circ}$. Because the declinations of the tuffites of M1t are intermediate, it may be argued that the rotation of Sardinia actually occurred during the sedimentation of the Aquitanian/ Langhian (Early Miocene) rock sequence of Castelsardo.

In summary, the lower time limit of the rotation, presumed on palaeomagnetic grounds, seems now rather well established as Late Oligocene/Early Miocene. The Castelsardo research suggests that the minimum age of the upper limit is indicated by the palaeomagnetic direction of unit $T_{2}$. The pre-Sarravallian age of these rocks could imply that the rotation was completed before the Middle Miocene, although this is at variance with the hypothesis that the crustal block of Sardinia had not completed its rotation until the Pliocene ${ }^{13}$.

This research was supported by the Netherlands Organization for the Advancement of Pure Research (ZWO).

\section{K. A. De Jong}

Department of Geology,

University of Cincinnati,

Cincinnati, Ohio

Laboratorio di Geologia,

Marina del CNR,

Bologna

\section{MANZONI}

T. Stavenga

F. VAN DIJK

Geological Institute

State University of Utrecht,

Utrecht

R. VAN DER VOO

Department of Geology and Mineralogy,

University of Michigan,

Ann Arbor

J. D. A. ZIJDERVELD

Palaeomagnetic Laboratory,

Fort Hoofddijk,

State University of Utrecht,

Utrecht

Received January 9, 1973.

1 Argand, E., Int. Géol. Congr., 173 (1922).

2 Carey, S. W.; A -Tectonic Approach to Continental Drift, 251 (Univ. Tasmania, Hobart, 1958).

3 Nairn, A. E. M., and Westphal, M., Palaeogeogr., Palaeoclim., Palaeoecol., 5, 179 (1968).

4 Stanley, D. J., and Mutti, E., Nature, 218, 32 (1968).

3 De Jong, K. A., Manzoni, M., and Zijderveld, J. D. A., Nature, 224, 67 (1969).

6 Zijderveld, J. D. A., De Jong, K. A., and Van der Voo, R., Nature, 226, 933 (1970).

7 Bobier, C., and Coulon, C., CR Acad. Sci., Paris, 270, 1434 (1970).

${ }^{8}$ Moretti, A., Redini, R., Perno, U., and Serra, G., $1: 100,000 \mathrm{Geol}$. Map No. 180 of Italy (Rome, 1959).

9 Deriu, M., Mem. Soc. Geol. Ital., 3, 675 (1962).

10 Moretti, A., Boll. Soc. Geol. Ital., 61, 3 (1942).
11 Maxia, C., and Pecorini, G., Giornale Geologia, 35, 345 (1969). 12 Alvarez, W., Nature Physical Science, 235, 103 (1972).

13 Manzoni, M., De Jong, K. A., Carobene, L., and Pasini, G., Giornale Geologia, 38, 5 (1970).

\section{Climatic Implications of Total Gas Content in Ice at Camp Century}

WHEN firn turns into ice through densification and recrystallization, the volume of atmospheric gas trapped as the pores close off depends in particular on the atmospheric pressure. The idea of a correlation between the total gas content and the site formation altitude of high polar ice has thus been suggested ${ }^{1}$. This concept received new consideration when observations of climatic changes based on the isotopic composition of ice sampled along high polar ice cores were carried out $^{2-4}$, because the variations in measured isotopic content depend not only on general climatic changes (especially temperature changes) but also on different parameters among which the site formation altitude of the ice could play an important part.

Here we present the results of twenty-five total gas content determinations (Fig. 1) on apparently unfractured samples taken from the $1,400 \mathrm{~m}$ deep core drilling carried out at Camp Century on the North Greenland ice sheet ${ }^{5}$. A careful study of the isotopic composition of this ice enabled the observation of climatic variations over more than $100,000 \mathrm{yr}$ (ref. 6). The total gas content of the ice was measured volumetrically in a MacLeod gauge once the sample has been melted in vacuum and the gas phase completely extracted with water vapour trapping.

The total gas content $V$ reduced to STP and $1 \mathrm{~g}$ of ice can be theoretically defined by

$$
V=\left(1 / \gamma_{\mathrm{c}}-1 / \gamma_{\mathrm{i}}\right) T_{0} P_{\mathrm{c}} / T_{\mathrm{c}} P_{\mathrm{o}}
$$

$\gamma_{c}$ and $\gamma_{1}$ being respectively the pore close-off density and the pure ice density at temperature $T_{\mathrm{c}}, T_{0}$ the standard temperature $(273.16 \mathrm{~K}), T_{\mathrm{c}}$ and $P_{\mathrm{c}}$ the in situ temperature $(\mathrm{K})$ and the average pressure of the gas occlusions at pore close-off, and $P_{0}$ the standard pressure.

If the climatic conditions of the formation site (temperature and pressure) are known, the measurement of $V$ permits a calculation of $\gamma_{c}$. Determinations for Byrd Station (Antarctica) and Camp Century show that the total gas content within the ice remains unchanged and that the close-off densities under present climatic conditions are practically identical $(0.822 \pm 0.003$ and $0.823 \pm 0.004)$ and in excellent agreement with the only other precise value that has been published ${ }^{7,8}$ : $0.824 \pm 0.004$ for site 2, Greenland.

Nevertheless, in the case of Camp Century, a sudden and significant decrease in the total gas content is observed below a depth of approximately $1,100 \mathrm{~m}$. This discontinuity corre- 